\title{
Intensification of the drying process of small seed oilseeds using micro- wave electromagnetic radiation
}

\author{
Ildar GANEEV ${ }^{1,2}$, Khasan KARIMOV $^{1}$, Shamil FAYZRAKHMANOV ${ }^{1}$, Ilgam MASALIMOV ${ }^{1}$, Valeri \\ PERMYAKOV $^{1}$
}

Received November 28, 2019; accepted March 3, 2020.

Delo je prispelo 28. novembra 2019, sprejeto 03. marca 2020

\begin{abstract}
Intensification of the drying process of small seed oilseeds using microwave electromagnetic radiation

Abstract: One of the important and crucial stages of postharvest treatment of rapeseed is drying. The purpose of the article is to improve the drying process of seeds of small seed oil crops using electromagnetic radiation of the microwave range in order to increase its productivity and determine the optimal operating parameters. The article describes the construction of a new microwave (UHF) dryer with a capacity of $200 \mathrm{~kg} \mathrm{~h}^{-1}$ for drying small-seeded crops. Curves were obtained that show the dependence of the heating temperature of seeds on microwave power, the effect of initial seed moisture and heating temperature on drying kinetics. The ratio of the stages of microwave heating and cooling was determined, which allows to increase the drying efficiency.

Key words: grain drying; rapeseed; electromagnetic radiation; drying kinetics; drying device
\end{abstract}

Pospeševanje sušenja majhnih semen oljnih poljščin z mikrovalovnim elektromagnetnim sevanjem

Izvleček: Eden od pomembnejših in ključnih postopkov pri požetveni obravnavi semen oljne ogrščice je sušenje. Namen prispevka je izboljšanje procesa sušenja majhnih semen oljnih rastlin $\mathrm{z}$ mikrovalovnim elektromagnetnim sevanjem $\mathrm{z}$ namenom povečanja produktivnosti in določiti optimalne operacijske parametre. Članek opisuje zgradbo novega mikrovalovnega (UHF) sušilnika $\mathrm{z}$ zmogljivostjo $200 \mathrm{~kg} \mathrm{~h}^{-1}$ za sušenje majhnih semen oljnih poljščin. Krivulje kažejo odvisnost temperature segretih semen od moči mikrovalovnega sušilnika, učinka začetne vlažnosti semen in odvisnost sušilne temperature od kinetike sušenja. Določeno je bilo razmerje med gretjem in hlajenjem mikrovalovnega sušilnika, ki omogoča povečanje učinkovitosti sušenja.

Ključne besede: sušenje zrnja; oljna ogrščica; elektromagnetno sevanje; kinetika sušenja; sušilnik

1 Federal State Budgetary Educational Establishment of Higher Education "Bashkir State Agrarian University", Department of Mechanics and machine construction, Ufa, Russia

2 Corresponding author, e-mail: ganeev.il11@rambler.ru 


\section{INTRODUCTION}

In agricultural practice, small seed oil crops such as rapeseed, mustard, and saffron milk, which are in great demand for agriculture and industry, are becoming increasingly important (Håkansson et al., 2013; Kovalyshyn, 2015; Kovalyshyn et al., 2015). One of the most important operations of oilseed cultivation technology is post-harvest seed treatment (Håkansson et al., 2013; Soares et al., 2016; Moreno et al., 2017). After ripening, rapeseed has a moisture content that amount from 14 to $27 \%$, and the recommended humidity for storage should be no more than 7 to $8 \%$. Due to the high humidity in the seeds of oilseeds, oxidative processes can begin, leading to a decrease in their quality. Therefore, timely drying will allow to maintain high sowing and technological qualities of seeds (Ganeev et al., 2009; Ganeev \& Masalimov, 2009; Masalimov et al., 2018).

Due to the lack of special technological equipment, drying of oilseed grain is performed on grain drying equipment, which are distinguished by type and method of action (Gabitov et al., 2018). Existing drying methods are mainly based on thermal effects on the material, which in turn leads to a deterioration in the quality of the finished product (Jokiniemi \& Ahokas, 2014; Skakov, Rakhadilov \& Sheffler, 2013).

The choice of drying equipment must be made taking into account the physical and mechanical parameters of a particular culture. It is necessary to classify them to determine the most optimal construction of dryers. Drying devices can be classified according to a number of features, the main ones being the method of supplying heat, the construction of the drying chamber, the operating mode, the state of the grain layer and the construction (GOST, 2008; Sutjagin et al., 2017). The most widespread is the direction of drying grain using the convective method of heat supply. The convective grain dryers are simple and most productive (Soares et al., 2016; Maier, 2017; Manikantan et al., 2018). However, these grain dryers are characterized by high metal consumption, high cost and high energy costs (Sutjagin et al., 2017). In shaft type grain dryers operating on gaseous and liquid fuels, when drying food and industrial grain crops, the regulated specific energy consumption should not exceed $4.56 \mathrm{MJ} \mathrm{kg}^{-1}$ of evaporated moisture, and 5.74 MJ kg ${ }^{-1}$ when drying seed grain (GOST, 2008). In practice, convective drying devices that operate without heat recovery consume up to $6 \mathrm{MJ} \mathrm{kg}^{-1}$ of evaporated moisture due to the fact that most of the thermal energy is carried away irrevocably by the drying agent.

On the territory of the Russian Federation, the drum and shaft grain dryers with convective heat supply are most common, which, when drying the seed, often lead to grain injury. In addition, in shaft dryers, grain is often subjected to local overheating, which in turn leads to protein denaturation in the germ (Shizhuang et al., 2017).

The main significant drawback of convective grain dryers is the high energy costs due to the occurrence of a temperature gradient in the material being dried, which leads to a decrease in the drying rate (Jokiniemi et al., 2015). One of the solutions to this drawback is the differentiation of the supply of thermal energy consisting in the alternation of heating the material with its cooling (Jokiniemi et al., 2015). With the development of technology and technics, recently drying methods such as microwave and thermos-radiation methods have begun to spread, the feature of which is the penetration of electromagnetic waves into the depth of the material being dried. This leads to heating of the inner part of the grain bypassing the outer layer (Rogov, 1988).

During infrared drying (thermal radiation), the rays are absorbed by the product, which ensures a more uniform heating of the material in depth compared to convective drying (Rogov, 1988). This, in turn, leads to a decrease in the temperature gradient and direct transfer of steam from inside to outside under the influence of the gradient of total pressure (Darvishi et al., 2013; Béttega et al., 2014; Zhao et al., 2017). It should be borne in mind that increasing the temperature of infrared heating can lead to damage to the grain germ. In turn, a forced decrease in the heating temperature leads to a decrease in the drying rate and, as a consequence, to an increase in the duration of the drying process, a decrease in the productivity of the dryer, and an increase in energy consumption (Rogov, 2015; Karimov et al., 2016; Martynov et al., 2018). The microwave drying is characterized by internal heating of the material (Li et al., 2014; Zhao et al., 2017). Therefore, thermal diffusion of moisture, directed from the center to the surface of the body, increases the speed of microwave drying. However, in the case of microwave drying of grain, in the absence of temperature and moisture control inside the grain, the probability of germ death due to possible local overheating is high (Ganeev, 2011; Fajzrahmanov et al., 2014; Fajzrahmanov, 2015).

At the moment, the problem of the dependence of grain temperature in the inner layers on the power of electromagnetic radiation from microwave is poorly studied. Therefore, the most promising direction is the development of a drying device based on microwave heating of the material and conducting experimental research to identify the operating parameters of the installation, which allows to obtain a high-quality finished product. The purpose of the study is to increase the 
drying efficiency of small seed oilseeds by applying microwave electromagnetic radiation.

\section{METHODS}

The choice of the type of dryer and drying method for a particular material is impossible without taking into account its physical and thermophysical properties. In addition, the correct use of the laws of heat and moisture transfer is necessary to determine the most suitable drying mode. The drying process is characterized by internal and external moisture transfer. The optimal combination of technological methods used to increase internal and external moisture transfer will significantly intensify the drying process.

The kinetics of moisture transfer in capillary-porous colloidal bodies, which include seeds of agricultural crops, is generally determined by the difference in its potentials (temperature, moisture content). The intensity of internal moisture transfer is described by the well-known equation of non-isothermal moisture conductivity:

$$
q_{m}=q_{m_{L}}+q_{m_{T}}=-a_{m} \cdot \rho_{0} \cdot \nabla U-a_{m} \cdot \delta \cdot \rho_{0} \cdot \nabla T,
$$

where is the density of the moisture conduction flux, $\mathrm{kg}\left(\mathrm{m}^{-2} \cdot \mathrm{h}^{-1}\right)$; is the flux density of thermal moisture conductivity, $\mathrm{kg}\left(\mathrm{m}^{-2} \cdot \mathrm{h}^{-1}\right)$; is the moisture diffusion coefficient in the grain, $\mathrm{m}^{2} \mathrm{~s}^{-1}$; is the density of absolutely dry grain, $\mathrm{kg} \mathrm{m}^{-3}$; is the thermogradient coefficient, $1 \mathrm{~K}^{-1}$; and are the gradients of concentration (moisture content) and temperature, $\mathrm{kg}_{\text {moist }}\left(\mathrm{kg}_{\text {dry matter }}^{-1} \mathrm{~m}^{-1}\right)$ and $\mathrm{K} \mathrm{m}^{-1}$.

In this equation, the first term characterizes the movement of moisture in the material under the influ- ence of a moisture gradient, and the second - under the influence of a temperature gradient. When convectively dried, the heat from the upper layers of the material is transferred to the inside, therefore, the gradientsandhave opposite signs, i.e. thermal moisture conduction impedes the advancement of moisture from the surface of the material to its surface (Fajzrahmanov, 2015).

As can be seen from equation (1), by reducing the inhibitory effect of thermal moisture conduction or by increasing the flow of moisture conduction, the intensity of internal moisture transfer can be increased. The moisture flow can be increased by increasing the moisture gradient. This can be achieved by exposing the material to electromagnetic radiation in the microwave range (Ganeev, 2011).

During microwave heating, the humidity and temperature gradients have the same orientation, and in this case, moisture is removed not only under the influence of thermodynamic forces, but also under the influence of excess pressure arising inside the material (Budnikov, 2008):

$$
q_{m}=-a_{m} \cdot \rho_{0} \cdot \nabla U-a_{m}^{T} \cdot \rho_{0} \cdot \nabla T-\gamma_{\rho} \cdot \nabla p
$$

where is the coefficient of molecular transfer of steam, $\mathrm{kg}\left(\mathrm{m}^{-1} \cdot \mathrm{s}^{-1} \cdot \mathrm{Pa}^{-1}\right)$; is the steam pressure gradient,

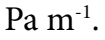

During microwave heating, the overpressure gradient sharply intensifies the internal mass transfer, while the transfer occurs both by molecular diffusion and by filtration through pores and capillaries. The mechanism of heat and moisture transfer during microwave heating compared with convective heating is shown in Figure 1.

When using microwave heating, the drying process is limited by external moisture transfer. Due to intensive

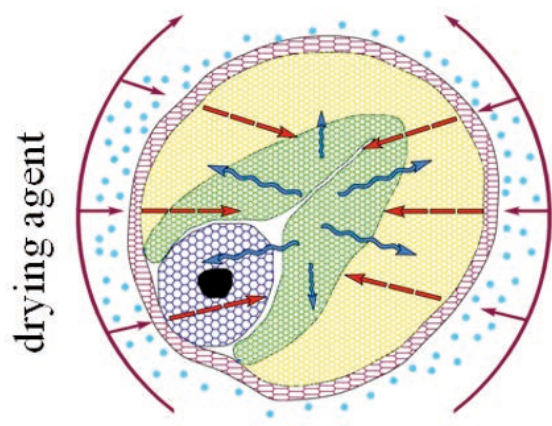

a)
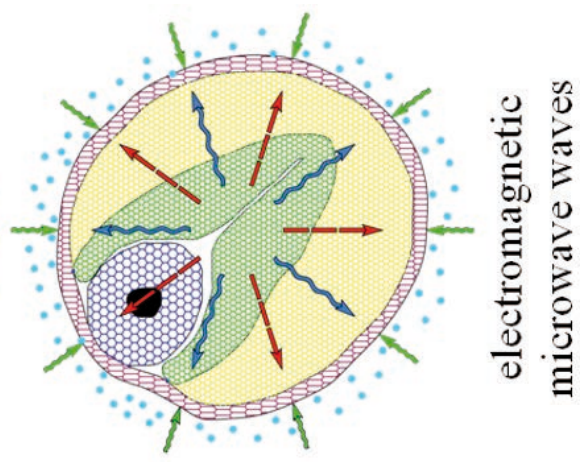

b)

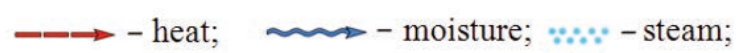

Figure 1: The mechanism of heat and moisture transfer with various heating methods $\mathrm{a}$ - convective heating; $\mathrm{b}$ - microwave heating 


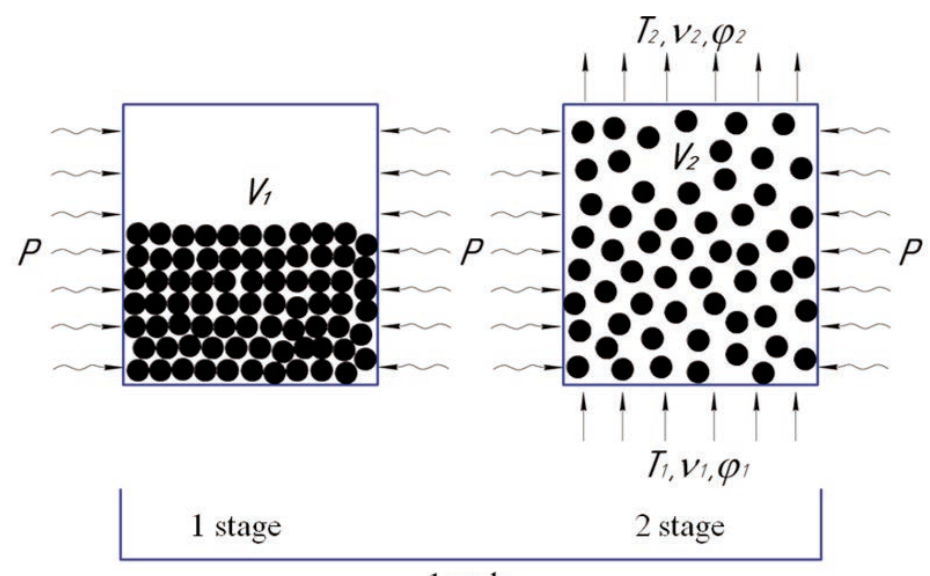

1cycle

Figure 2: Technological scheme of the drying process

$\mathrm{P}$ - microwave E energy flows; V1 and V2 - the volume occupied by seeds at stages 1 and 2 of drying; T1, v1, $\varphi 1$ - temperature, speed and humidity of the air flow at the entrance to the seed layer; T2, v2, $\varphi 2$ - temperature, speed and humidity of the air flow at the exit of the seed layer.
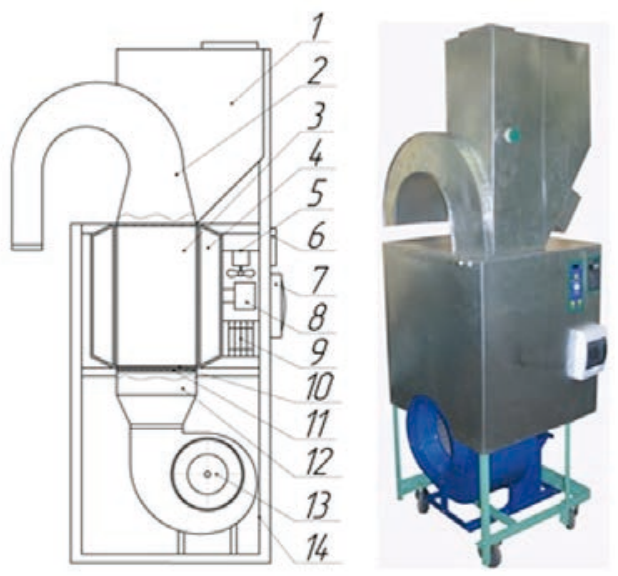

Figure 3: Microwave dryer

1 - hopper; 2 - unloading device; 3 - drying chamber; 4 - resonator chamber; 5 - magnetron cooling system; 6 - control panel; 7 start-up protection block; 8 - magnetron with a waveguide; 9 - inverter; 10 - wireless radio-transparent mesh; 11 - shielding mesh; 12 - air distribution channel; 13 - fan; 14 - frame

movement, moisture leaving the inner layers condenses on the surface of the material and creates a barrier layer that prevents further moisture transfer. Therefore, the use of only microwave energy for drying is impractical.

By increasing the speed of the drying agent and increasing the active surface of the material, an increase in external moisture transfer can be achieved (Friesen et al., 2014). For small seed crops, drying in a fluidized bed is recommended. When drying in a fluidized bed, the active surface of the material increases to $100 \%$, which ensures the greatest uniformity of drying.

The technological scheme of drying small seed oilseeds has been developed, which allows to significantly intensify the drying process and reduce the risk of pro- longed exposure to high temperatures on the dried material. According to the developed scheme, the drying process consists of several cycles, each of which includes two stages (Figure 2). At the first stage, the drying object is heated to the required temperature by exposure to $\mathrm{mi}$ crowave electromagnetic radiation. At this stage, there is an intensive release of moisture from the material, which accumulates on its surface. At the second stage, the material is cooled by atmospheric air in a fluidized bed. At this stage, the moisture is removed from the surface of the material and cooling is performed to the required temperature. Due to cooling in the fluidized bed, heat and moisture transfer are intensified, and uniform mixing of material particles occurs. 
The drying technological scheme is implemented in a microwave drying unit developed at Bashkir State Agrarian University, the novelty of technical solutions of which is confirmed by the patent of the Russian Federation for invention. The scheme and photo of the drying unit are shown in Figure 3.

The device consists of a frame on which a resonator chamber with a built-in drying chamber is installed; a hopper and an unloading device are located above it. The drying chamber is made of radiolucent material (fluoroplast F4) in the form of a cylinder. The drying chamber is connected to a fan through an air distribution channel. A magnetron with a maximum power of $\mathrm{P}_{\mathrm{H}}=850 \mathrm{~W}$ and a set oscillation frequency of $2.45 \mathrm{GHz}$ is connected to the resonator chamber through a rectangular waveguide.

To study the influence of the main factors on the drying process, rapeseed was selected as the drying object.

Of the many factors affecting the drying process, four main ones were chosen: $W_{\mathrm{H}}$ - initial seed moisture, $P$ - microwave power; $T$ - seed heating temperature; $t_{\text {exp }}$ is the exposure time of microwave heating. The limits of factors change are given in Table 1.

The intervals of variation of factors were revealed based on the study of the researchers (Budnikov, 2008), as well as taking into account the technological requirements and construction features of the drying unit.

The studies were performed in triplicate. The reproducibility error was estimated from parallel experiments on the basis that the setting of parallel experiments, as a rule, does not give completely identical results (Ganeev, 2011; Martynov et al., 2018; Masalimov et al., 2018). According to parallel observations, the variance of reproducibility was determined. The homogeneity of the dispersions was checked using the Cochren test, the calculated value of which was compared with tabular data. The verification of individual regression coefficients for significance was carried out using Student's test at a significance level of $p=0.05$. The adequacy of the obtained model was checked according to the Fisher criterion at a significance level of $p=0.05$. The processing the results of the experiments, as well as calculating the calculated values of the criteria, was carried out using the software packages "Statistica" and "Mathcad". The experiments were conducted to identify the effect of the power of microwave electromagnetic radiation on changes in seed temperature. And we also studied the influence of the main mode parameters on the kinetics of drying of seeds, which allows to determine the basic laws of the drying process.

When studying the influence of microwave electromagnetic radiation power on temperature changes, the initial seed moisture was $=14.4 \%$; the drying was carried out at a conditional humidity $W_{K}=8 \ldots 8.5 \%$. The power by microwave electromagnetic radiation was regulated in the range $P=470 \ldots 850 \mathrm{~W}$. The microwave power was a variable parameter, and the initial humidity and seed heating temperature were constant.

When studying the influence of the main operating parameters on the drying kinetics, the influence of the initial moisture and the temperature of heating the seeds on the drying kinetics was revealed. In the first case, the variable parameter was the initial humidity, which varied in the range $13 \ldots 25 \%$, which corresponds to the values of the harvesting moisture of seeds of agricultural crops in most regions of Russia. The power of the microwave electromagnetic radiation was constant and equal to $P=850 \mathrm{~W}$, the maximum heating temperature of the seeds was also the same for all experiments $-T=50^{\circ} \mathrm{C}$. In the second case, the variable parameter was the heating temperature of the seeds, and the microwave power and the initial humidity were constant $P=850 \mathrm{~W}, W_{H}=$ $14.3 \%$. The temperature of heating the seeds during drying was in the range $T=40 \ldots 70^{\circ} \mathrm{C}$. The temperature was measured throughout the drying process using infrared temperature sensors. Additionally, the temperature in the seed layer was measured with kerosene thermometers, which are not affected by electromagnetic radiation.

The drying process of seeds was carried out in accordance with the developed technological scheme. At the first stage of each cycle, the seeds were heated under the influence of electromagnetic radiation in the microwave range, at the second stage, the shift was cooled in the fluidized bed. The air temperature supplied for cool-

Table 1: The limits of factors change

\begin{tabular}{|c|c|c|c|c|c|}
\hline \multirow[t]{3}{*}{ Terms of planning } & \multirow[t]{3}{*}{ Coded value } & \multicolumn{4}{|c|}{ Factors value in the plan points } \\
\hline & & $\mathrm{x}_{1}$ & $\mathrm{x}_{2}$ & $\mathrm{x}_{3}$ & $\mathrm{x}_{4}$ \\
\hline & & $W_{\mathrm{H}}, \%$ & $\mathrm{P}, W$ & $T,{ }^{\circ} \mathrm{C}$ & $t_{\exp }, \mathrm{C}$ \\
\hline Main interval & 0 & 18 & 550 & 45 & 22,5 \\
\hline Variation interval & $\Delta$ & 7 & 300 & 15 & 17,5 \\
\hline Upper level & +1 & 25 & 850 & 60 & 40 \\
\hline Lower level & -1 & 11 & 250 & 30 & 5 \\
\hline
\end{tabular}


ing the seeds was $20 \ldots 27^{\circ} \mathrm{C}$, which is close to the average monthly air temperature during grain harvesting.

In addition, convection drying and full-cycle microwave drying were carried out. The rape seeds with an initial moisture content of $W_{H}=25 \%$ were dried to a conditional moisture content of $W_{K}=7 \ldots 8 \%$, with a maximum heating temperature of seeds to $38 \ldots 40^{\circ} \mathrm{C}$. The temperature of the drying agent during convective drying did not exceed $60 \ldots 65^{\circ} \mathrm{C}$.

\section{RESULTS AND DISCUSSION}

The preliminary research results showed that the intensity of the temperature increase of rapeseed when exposed to electromagnetic radiation from microwave significantly depends on the initial humidity. At high initial humidity, the temperature of the seeds rises more intensively (Figure 4). This is due to the change in the value of the coefficient of dielectric loss, and as a consequence, a change in the amount of heat accumulated in the seeds.

At the initial stage of heating - $20 \ldots 25$ seconds, the temperature of the seeds changes insignificantly, especially for seeds with low initial humidity (Figure 5). Further, the intensity of temperature changes increases sharply. The higher the initial seed moisture, the faster the temperature rises. The high rate of change in seed temperature is observed up to a heating temperature of $75 \ldots 80^{\circ} \mathrm{C}$. Further, the intensity of the temperature increase decreases.

From the graphs shown in Figures 4 and 5 it can be seen that with a microwave $E$ power of $P=850 \mathrm{~W}$, the change in seed temperature is on average 1.5 ... 2 times faster than with a power of $P=470 \mathrm{~W}$. Therefore, the temperature of the seeds during microwave heating is highly dependent on the power of electromagnetic radiation. The higher the power of electromagnetic radiation, the more intensively the temperature rises.

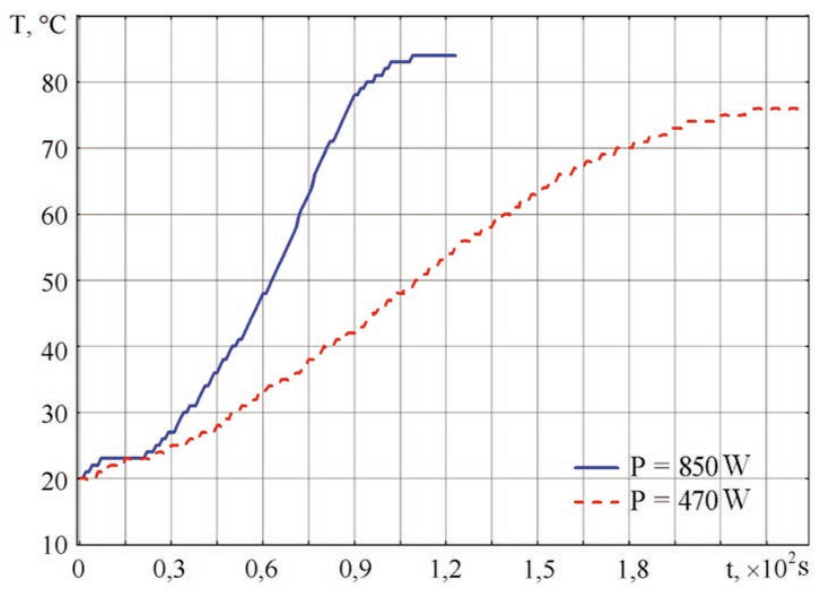

Figure 4: Graphs of the temperature change in of rapeseed when microwave heating $(\mathrm{WH}=22 \%)$

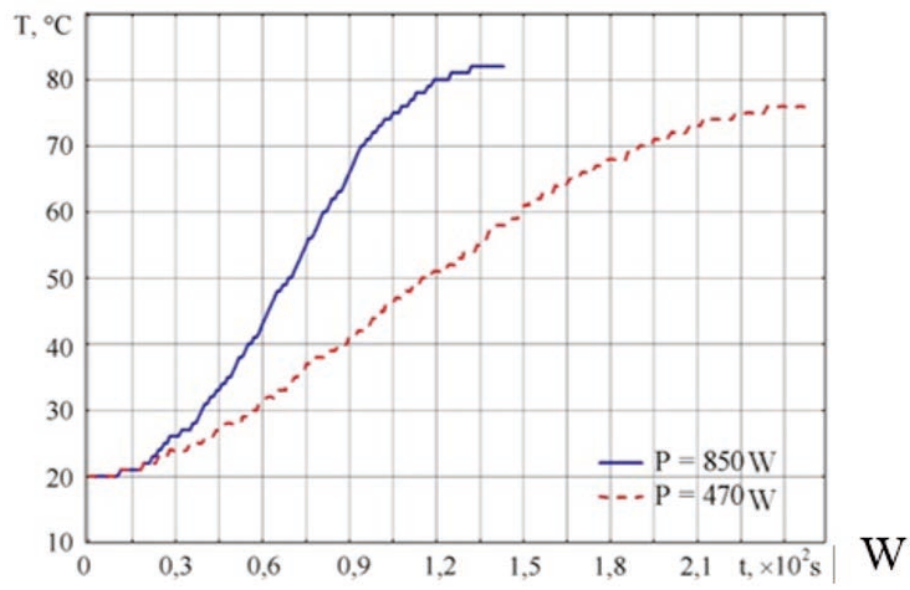

Figure 5: Graphs of the temperature changes of rapeseed at microwave heating $(\mathrm{WH}=16 \%)$ 
The study results of the effect of the initial seed moisture on the drying kinetics show that, at a high initial humidity $W_{H}=25 \%$, there is a sharp decrease in seed moisture at the initial time, due to the high speed of the first drying period. In experiments where seeds with an initial humidity of close conditional humidity $W_{H}=13.5$ and $15 \%$ were studied, this was not observed, the drying speed is not high even at the initial stage (Figure 6). Many researchers have noted the effect of initial seed moisture on increasing the drying rate in the first period (Gabitov et al., 2018; Martynov et al., 2018).

As can be seen from the graphs, the kinetics of drying using microwave heating significantly depends on the initial moisture content of the seeds. The critical humidity value also depends on the initial moisture content of the seeds. The higher it is, the greater the first critical humidity.

In convective drying due to insufficient supply of moisture from the internal parts of the material to the surface, the deepening of the evaporation zone occurs which leads to a continuous increase in the temperature of the material (Ganeev, 2011; Fajzrahmanov, 2015). The beginning of the temperature increase of the material indicates a transition from a period of constant drying speed to a period of decreasing drying speed. This transition is determined by the critical humidity, the value of which is influenced by the initial moisture of the material, the temperature of the drying agent, and the form of contact of moisture with the material. Unlike the temperature of the drying agent, the influence of microwave power on critical humidity is negligible. Therefore, the transition from a period of a constant speed of drying to a period of a decreasing speed of drying is determined mainly by the forms of the connection of moisture with the material.

One of the main parameters affecting the drying process is the value of the final temperature for heating the seeds. Figure 7 shows the graphs of the drying

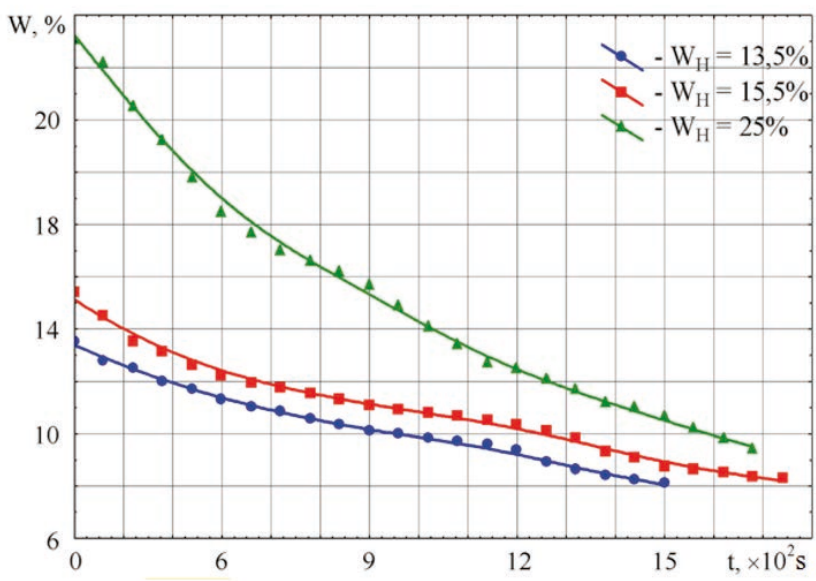

Figure 6: Curves of drying rape seeds with different initial humidity

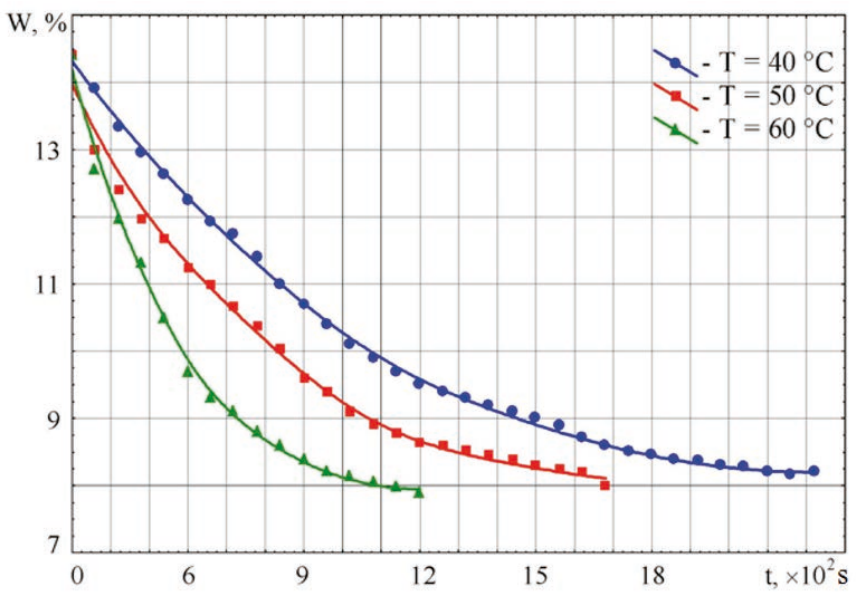

Figure 7: Curves of drying rapeseed at different temperatures of seed heating 
of rape seeds with various final temperatures for heating the seeds. The analysis of the obtained curves shows that high-temperature microwave heating significantly reduces drying time.

The results of previous studies have shown that the value of the initial humidity affects the heating rate of seeds (Ganeev, 2011; Martynov et al., 2018; Masalimov et al., 2018). Therefore, for drying seeds with high initial humidity, it is necessary to select milder drying modes.

Drying rapeseed and other crops with high microwave power and temperature can lead to the destruction of the biological structure of seeds, reducing technologi$\mathrm{cal}$ and sowing indicators. When choosing microwave power and drying temperature, it is necessary to take into account the final purpose of the seeds.

The results of studying the dynamics of seed heating showed that the temperature of seeds during microwave heating increases rapidly, so it is necessary to maintain the optimum temperature of the seeds during microwave drying, which does not lead to a decrease in their quality.

According to the selected technological scheme of drying at the second stage, it was planned to purge the drying object with atmospheric air in order to cool it. It was noted that cooling in the pseudo-fluidized bed facilitates the rapid and uniform removal of moisture from the surface of the drying object. It should be noted that the timely start of the cooling stage avoids heating to a critical temperature, leading to a decrease in seed quality. The researchers found that for the organization of the pseudo-fluidized bed of rapeseed should be equal to 1.5 ... $2.3 \mathrm{~m} \mathrm{~s}^{-1}$ (Fajzrahmanov, 2015; Kovalyshyn et al., 2015).

For the developed microwave drying device, the optimal value of the air flow rate was established experimentally, which allows uniformly mixing rape seeds in a pseudo-fluidized bed. With an air flow rate of $0.7 \ldots 1 \mathrm{~m}^{3}$ $\mathrm{s}^{-1}$, the velocity at the exit from the seed layer was $1.8 \ldots$ $2.1 \mathrm{~m} \mathrm{~s}^{-1}$. To determine the most effective combination of drying steps, two alternatives of the drying steps were considered: 1 - heating the seeds to the required temperature and blowing in the fluidized bed until a constant temperature is reached; 2 - heating of seeds to the required temperature and cooling by $5 \ldots 15^{\circ} \mathrm{C}$.

Figure 8 shows the kinetics curves of microwave drying of rapeseed with periodic cooling in the fluidized bed until a constant seed temperature is reached.

The analysis of the drying kinetics graph (Figure 8), on each cycle, the nature of the temperature change is different. After each cooling cycle, the final temperature is higher than the previous one. Moreover, with a decrease in the moisture content of the material to $10 \ldots 9 \%$, the temperature of the seeds rises sharply. The explanation for this may be the onset of critical humidity, at which the transition from a period of constant to a period of decreasing drying speed begins. The period of decreasing drying rate is characterized by a continuous increase in temperature, and a continuous decrease in the drying rate (Ganeev et al., 2018). The implementation of this option of the cooling stage is difficult due to the difference in the final temperature between the cycles, which does not allow to precisely determine the time allotted to the cooling stage.

The results of the study of the kinetics of drying made it possible to establish the optimal ratio of the duration of the drying stages. At the first stage, microwave heating of the seeds to the required temperature is carried out, and at the second stage, by cooling with a decrease in the temperature of the seeds by $10^{\circ} \mathrm{C}$ from the drying temperature. In the course of this research, it was

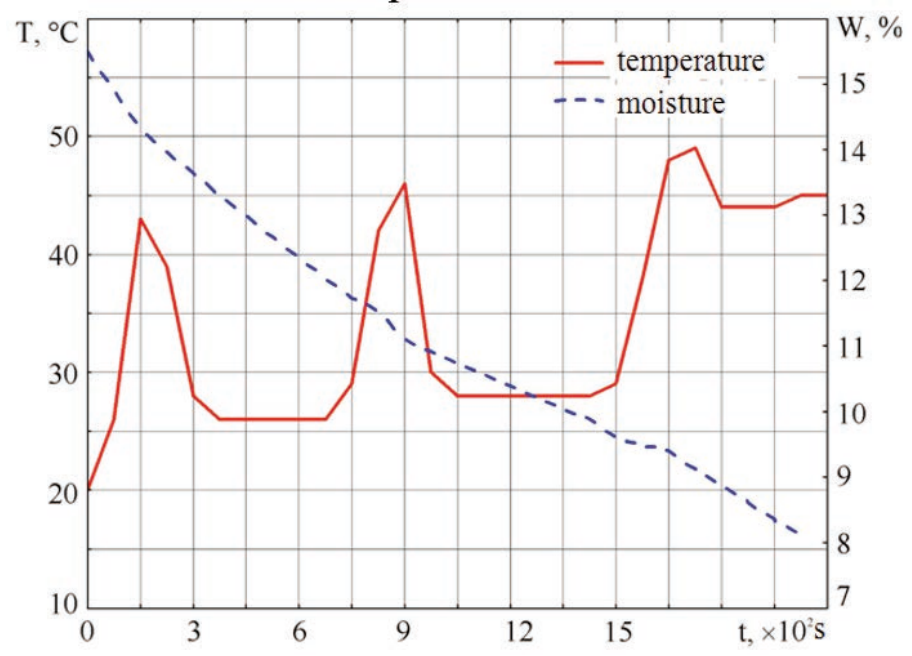

Figure 8: Kinetics of microwave drying of rapeseed with periodic cooling to a constant temperature $(\mathrm{P}=850 \mathrm{~W}, \mathrm{WH}=15.5 \%$, Tavg $\left.=45^{\circ} \mathrm{C}\right)$ 
found that when the seeds are cooled by $5 \ldots 6^{\circ} \mathrm{C}$, there is uneven cooling of the seeds along the layer thickness. The cooling at $13 \ldots 15{ }^{\circ} \mathrm{C}$ led to unreasonable energy consumption due to the continuous operation of the fan. Taking into account the cooling time of the seeds, uniformity of cooling across the layer thickness and energy consumption, the optimal value of the change in the temperature of the seeds at the cooling stage corresponding to $8 \ldots 10^{\circ} \mathrm{C}$ was established. At these temperatures, the duration of the first and second stages are in the same time interval and amount to 1.5 ... 2 minutes, depending on the microwave power. Depending on the initial humidity, the conditioned moisture of the rapeseed is achieved in $8 \ldots 12$ drying cycles.

Figure 9 shows the graphs of the drying of rapeseed with periodic cooling at $8 \ldots 10{ }^{\circ} \mathrm{C}$ from the drying temperature. From the graphs it is seen that the dynamics of heating between cycles in this case is also different, but no sharp jumps in temperature are observed. This scheme of alternating stages allows you to fully automate the drying process and select the operating modes of the microwave drying unit.

The results of comparative experiments of convective and microwave drying of rapeseed are shown in Figure 10 .

The analysis of the drying curves shows that the use of microwave energy of electromagnetic radiation for drying rapeseed can reduce the drying time, in comparison with the convective method, by $1.5 \ldots 1.7$ times. In addition, microwave drying does not contaminate

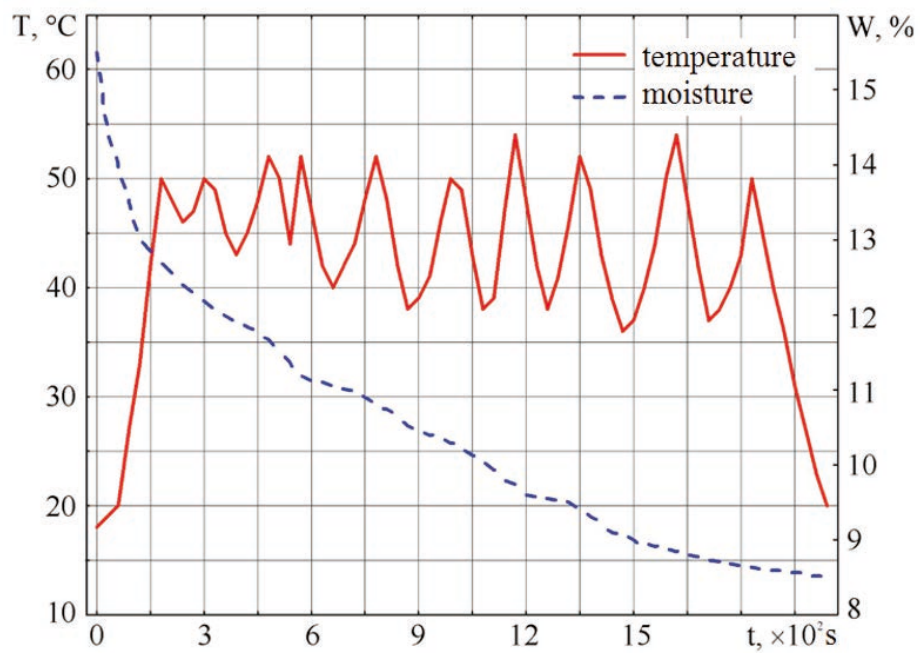

Figure 9: Kinetics of microwave drying of rapeseed with periodic cooling at $8 \ldots 10^{\circ} \mathrm{C}\left(\mathrm{P}=600 \mathrm{~W}, \mathrm{WH}=15.5 \%\right.$, Tavg $\left.=45^{\circ} \mathrm{C}\right)$

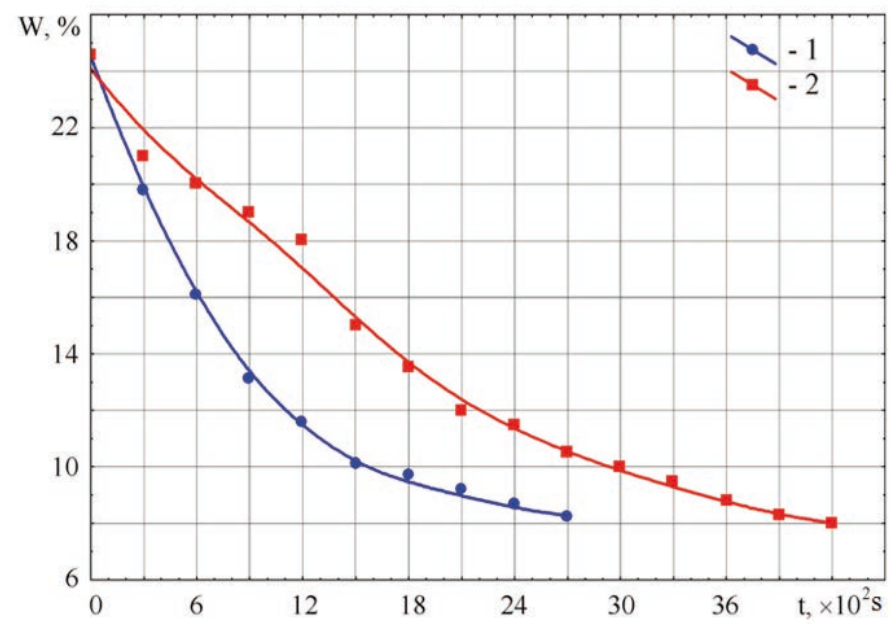

Figure 10: Curves of drying rape seeds with different ways ( $\mathrm{WH}=25 \%)$

1 - MICROWAVE drying $\left(\mathrm{P}=850 \mathrm{~W}, \mathrm{~T}=38 \ldots 40^{\circ} \mathrm{C}\right) ; 2$ - convective drying $\left(\right.$ Ta.s $\left.=60 \ldots 65^{\circ} \mathrm{C}, \mathrm{T}=38 \ldots 40^{\circ} \mathrm{C}\right)$ 
the seeds and the surrounding air with fuel combustion products as in convective drying.

In the study area involved in the problem of drying small-seeded crops, works are devoted to increasing the drying efficiency by improving the convective drying method, which is traditional for most countries. Using the energy of electromagnetic radiation from the microwave range for drying small seed oilseeds is poorly studied. In other studies dealing with the problems of using microwave energy for drying crops, in most cases, microwave heating is considered as an additional source of heat to convective heating. Drying modes with short-term (2-3 sec.) exposure to high-power microwave electromagnetic radiation are proposed, which leads to overheating and loss of seed quality of grain. Furthermore, some researchers suggest using microwave heating as a preliminary before convective drying or active ventilation of the grain, which can lead to an increase in energy costs for performing these operations (Fajzrahmanov, 2015; Ganeev, 2011). Our studies have confirmed the possibility of using the energy of electromagnetic radiation from the microwave range as the main heating method for drying materials without the use of additional heating methods. The use of microwave heating can significantly intensify the drying process of small seed oilseeds, while maintaining their technological and sowing qualities.

\section{CONCLUSIONS}

The construction of a microwave drying device in which a two-stage technological scheme of drying is implemented is proposed. At the first stage, the seeds are heated to the required temperature, by exposing them to electromagnetic radiation in the microwave range. At the second stage, the seeds are cooled with outside air in a pseudo-fluidized bed. Based on the results of the drying kinetics study, the optimal ratios of the duration of its stages were determined, according to which, after heating to the desired temperature, cooling at $8 \ldots 10{ }^{\circ} \mathrm{C}$ from the set temperature follows at the first stage. At the same time, the conditional seed moisture content of 7 ... $8 \%$, depending on the initial importance, is achieved in $8 \ldots 12$ cycles. The preliminary research results showed that the use of microwave energy of electromagnetic radiation for drying rapeseed can reduce the drying time, compared with the convective method, by 1.5 ... 1.7 times. The rational drying mode was determined: microwave power $P$ $=600 \mathrm{~W}$, seed heating temperature $T=50{ }^{\circ} \mathrm{C}$, exposure time of microwave heating $t_{\text {exp }}=20 \mathrm{~min}$. With these parameters of the mode, the quality of the dried seeds is at a satisfactory level and the minimum heat consumption is $Q_{\text {sat }}=4.1 \mathrm{MJ} \mathrm{kg}^{-1}$ of moisture, which is 1.4 times lower than in convection-type dryers. The proposed drying method can be used both in agricultural production and in the food and chemical industries. As studies have shown, this drying method allows to increase the productivity of the process compared to existing methods. Using microwave energy in the developed drying device makes it possible to use it as a universal device for drying, disinfecting and biostimulating seeds.

\section{REFERENCES}

Béttega, R., Rosa, J. G., Corrêa, R. G., \& Freire, J. T. (2014). Comparison of carrot (Daucus carota) drying in microwave and in vacuum microwave. Brazilian Journal of Chemical Engineering, 31(2), 403-412. https://doi.org/10.1590/01046632.20140312s00002668

Budnikov, D. A. (2008). Intensification of grain drying by active ventilation using a microwave electromagnetic field (dis. ... cand. of tech. sciences).

Darvishi, H., Khoshtaghaza, M. H., Najafi, G., \& Zarein, M. (2013). Characteristics of sunflower seed drying and microwave energy consumption. International Agrophysics, 27(2), 127-132. https://doi.org/10.2478/v10247-012-0077-8

Fajzrahmanov, Sh. F. (2015). Development of a microwave conveyor installation for drying sunflower seeds with justification of its parameters and operating modes. (dis. ... cand. of tech. sciences), Ufa.

Fajzrahmanov, Sh. F., Ganeev, I. R. and Masalimov, I. H. (2014). Patent № 139803, MPK F26B 14/04 Multifunctional microwave conveyor system for drying and microwave processing of bulk materials, 2012112040/06; application 18.03.2013; published 20.04.2014, Bulletin, No 11, Russian Federation.

Friesen, A. P., Conner, R. L., Robinson, D. E., Barton, W. R., \& Gillard, C. L. (2014). Effect of microwave radiation on dry bean seed infected with Colletotrichum lindemuthianum with and without the use of chemical seed treatment. $\mathrm{Ca}$ nadian journal of plant science, 94(8), 1373-1384. https:// doi.org/10.4141/cjps-2014-035

Gabitov, I. I., Badretdinov, I. D., Mudarisov, S. G., Khasanov, E. R., Lukmanov, R. L., Nasyrov, R. R., ... \& Pavlenko, V. A. (2018). Modeling the process of heap separation in the grain harvester cleaning system. Journal of Engineering and Applied Sciences, 13(S8), 6517-6526.

Ganeev, I. R. (2011). Improving the drying efficiency of rapeseed using electromagnetic radiation. Ufa.

Ganeev, I. R., \& Masalimov, I. H. (2009). Choosing the optimal grain dryer construction for drying rapeseed. In: International scientific and technical conference dedicated to the 75th anniversary of the foundation of the Irkutsk State Aricultural Academy "Climate, Ecology, Agriculture of Eurasia" (p. 417-420). Irkutsk.

Ganeev, I. R., Efimov, A. V., \& Saitov, B. N. 2009. The effect of the microwave emitter on the cells of rapeseed grains during their drying. In: III All-Russian scientific-practical conference "Youth science and agribusiness: problems and prospects." (p. 78-81). Ufa: Bashkir State Agrarian University. 
GOST (2008), Mine grain dryers. Power consumption indicators. State Standard 28293-89. Moscow: Standartinform.

Håkansson, I., Arvidsson, J., Etana, A., Rydberg, T., \& Keller, T. (2013). Effects of seedbed properties on crop emergence. 6. Requirements of crops with small seeds. Acta Agriculturae Scandinavica, Section B-Soil \& Plant Science, 63(6), 554563. https://doi.org/10.1080/09064710.2013.822540

Jokiniemi, H. T., \& Ahokas, J. M. (2014). Drying process optimisation in a mixed-flow batch grain dryer. Biosystems engineering, 121, 209-220. https://doi.org/10.1016/j.biosystemseng.2014.01.002

Jokiniemi, T., Oksanen, T., \& Ahokas, J. (2015). Continuous airflow rate control in a recirculating batch grain dryer. Agronomy Research, 13(1), 89-94.

Karimov, Kh. T, Ganeev, I. R., Masalimov, I. Kh., Permjakov, V. N., \& Fajzrakhmanov, Sh. F. (2016). Device for drying and sorting bulk material. Invention № 2577909, Cl. F26B20/00 Bull. No 8, Russian Federation, Int.

Kovalyshyn, S. (2015). Improving The Quality Of Seeds Of Small Seeded Crops By Separating Biologically Inferior Seeds. Mechanization in agriculture \& Conserving of the resources, 61(5), 17-21.

Kovalyshyn, S., Dadak, V., \& Konyk, S. (2015). Intensification of the Process of Preparing Small Seed Crop Mixtures. Acta Technologica Agriculturae, 18(4), 108-112. https://doi. org/10.1515/ata-2015-0021

Li, S., Cao, S., \& Meng, W. (2017, June). Construction of Grain Dryers' Control System. In IOP Conference Series: Materials Science and Engineering (Vol. 212, No. 1, p. 012017). IOP Publishing. https://doi.org/10.1088/1757899X/212/1/012017

Li, Y., Zhang, T., Wu, C., \& Zhang, C. (2014). Intermittent microwave drying of wheat (Triticum aestivum L.) seeds. Journal of Experimental Biology and Agricultural Sciences, 2(1), 32-36.

Maier, D. E. (2017). Grain Drying, Handling, and Storage Handbook. MidWest Plan Service, Iowa State University.

Manikantan, M. R., Barnwal, P., \& Goyal, R. K. (2014). Dry- ing characteristics of paddy in an integrated dryer. Journal of food science and technology, 51(4), 813-819. https://doi. org/10.1007/s13197-013-1250-1

Martynov, V. M., Gabitov, I. I., Karimov, K. T., Masalimov, I. K., Permyakov, V. N., Ganeev, I. R., ... \& Saitov, B. (2018). Reasoning Barley Grain Drying Modes For Vacuum-Infrared Drying Machines. Journal of Engineering and Applied Sciences, 13(S11), 8803-8811.

Masalimov, I. K., Faizrakhmanov, S. F., Gabitov, I. I., Martynov, V. M., Permyakov, V. N., Aipov, R. S., ... \& Ramazanov, A. S. (2018). Optimal operating modes reasoning of sunflower seeds microwave drying in a conveyor type unit. Journal of Engineering and Applied Sciences, 13(S8), 6570-6575.

Moreno, Á. H., Hernández, R., \& Ballesteros, I. (2017). Microwave drying of seeds of agricultural interest for Ecuador. Ampere Newsl, 92, 28-32.

Rogov, I. A. (1988). Electrophysical methods of food processing. M.: IN "Agropromizdat.

Skakov, M., Rakhadilov, B., \& Sheffler, M. (2013). Influence of Electrolyte Plasma Treatment on Structure, Phase Composition and Microhardness of Steel P6M5. In Key Engineering Materials (Vol. 531, pp. 627-631). Trans Tech Publications Ltd. https://doi.org/10.4028/www.scientific.net/KEM.531532.627

Soares, M. A. B., Jorge, L. M. D. M., \& Montanuci, F. D. (2016). Drying kinetics of barley grains and effects on the germination index. Food Science and Technology, 36(4), 638-645. https://doi.org/10.1590/1678-457x.11916

Sutjagin, S. A., Kurdjumov, V. I., Pavlushin, A. A., \& Dolgov, V. I. (2017). Reducing specific energy costs for drying grain in a contact type plant. Bulletin of the Samara State Agricultural Academy, 2, 39-45. https://doi.org/10.12737/ article_58f847e2b43fe0.64340630

Zhao, Y., Jiang, Y., Zheng, B., Zhuang, W., Zheng, Y., \& Tian, Y. (2017). Influence of microwave vacuum drying on glass transition temperature, gelatinization temperature, physical and chemical qualities of lotus seeds. Food chemistry, 228, 167-176. https://doi.org/10.1016/j.foodchem.2017.01.141 